\title{
CHLOROQUINE AND HYDROXYCHLOROQUINE: A MAJOR BREAKTHROUGH FOR COVID-19
}

\author{
KRITIKA VERMA*, INDER KUMAR
}

School of Pharmacy, Abhilashi University, Mandi, HP, India

Email: inder.93kumar@gmail.com

Received: 19 Jul 2020, Revised and Accepted: 12 Aug 2020

\begin{abstract}
Coronavirus pandemic or COVID-19 is a global public health emergency at this period. Presently, no pharmacological treatment is known to treat this condition. Hydroxychloroquine (HCQ), a derivative of chloroquine (CQ), was first synthesized in 1946 by adding a hydroxyl group to CQ, which is much less toxic than CQ in animal studies. Other than being an anti-malarial drug, it was revealed to have various pharmacological effects and one of those is its anti-viral property. CQ, as well as HCQ, has been used in SARS (Severe Acute Respiratory Syndrome) coronavirus infection due to its antiviral properties. Even though various scientists have considered HCQ as a better therapeutic approach than CQ for the treatment of coronavirus infection, there are various adverse drug reactions associated with HCQ treatment in COVID-19 patients. In this paper, we review the anti-viral mechanism, various adverse drug reactions, and side effects of HCQ for COVID-19 treatment.
\end{abstract}

Keywords: Hydroxychloroquine, Chloroquine, Coronavirus, Severe acute respiratory syndrome

(C) 2020 The Authors. Published by Innovare Academic Sciences Pvt Ltd. This is an open access article under the CC BY license (http://creativecommons.org/licenses/by/4.0/] DOI: http://dx.doi.org/10.22159/ijpps.2020v12i10.39121. Journal homepage: https://innovareacademics.in/journals/index.php/ijpps.

Speedy peer review was done as the subject of the manuscript was related with pandemic.

\section{INTRODUCTION}

Hydroxychloroquine (HCQ) goes to the group of antimalarial agents, but the gratitude of its assistance in various diseases other than malaria dates back to 1894 when Payne stated that quinine was effective in cutaneous lupus [1]. Chloroquine (CQ) and HCQ were revealed to have many immunomodulatory effects and have a conventional role in the administration of rheumatic infections, such as rheumatoid arthritis and systemic lupus erythematosus, skin diseases and in the management of chronic fever. Later, other metabolic, cardiovascular, antithrombotic, and antineoplastic effects of HCQ were shown. Wallace et al. found that HCQ was also revealed to have a promising result on lipid profiles in patients with rheumatic diseases [2].

Its additional beneficial effects were also shown periodically in other diseases. It was shown to be very effective in KFD i.e. KikuchiFujimoto disease, a benevolent disease categorized by lymphadenopathy, fever, and leukopenia usually happens in young women [3, 4]. Sarcoidosis induced skeletal and metabolic effects were effectively cured with HCQ in patients usually who were not candidates for glucocorticoid treatment. It also enabled steroid discontinuation in patients with subglottic stenosis [5-7].

Besides, HCQ was found to be active against bacterial as well as viral infections. In 2002-2003, an immediate pandemic of severe critical respiratory syndrome was caused due to Human coronavirus (hCoV). To date, no particular antiviral drugs are existing for the inhibition or management of hCoV infection. In vitro studies showed that CQ inhibits the repetition and spread of coronavirus and stops infection with hCoV in neonatal mice [8-10].

Presently, an epidemic of cases through unexplainable low respiratory infections detected in the major urban area in China's Hubei province i.e. Wuhan, was first informed to the WHO Republic Office in China on December 31, 2019. At first, the causative agent was unidentifiable and these primary cases were characterized as "pneumonia of unknown etiology." The root of this disease is now recognized as an innovative virus belonging to the coronavirus (CoV) family.

On February 11, 2020, the disease caused by this new CoV was announced as "COVID-19," i.e. "coronavirus disease 2019" by WHO Director-General, Dr. Tedros Adhanom Ghebreyesus [11]. This new virus appears to be extremely contagious and has rapidly spread all over the world. As on $1^{\text {st }}$ March 2020, a total of 7,169 confirmed cases of COVID-19 had been reported globally, while on June 17,
$2020,13,616,593$ confirmed cases along with 585,727 deaths had been reported globally, of which 1,003,832 cases and 25,602 deaths were in India, according to WHO [WHO Situation Report 179]. The number of COVID-19 cases is still on the rise.

There is no precise antiviral treatment suggested for COVID-19, and no vaccine is presently available. The treatment is symptomatic, and oxygen therapy signifies the major treatment involvement for patients with a major infection. Automated ventilation may be compulsory in cases of respiratory failure refractory to oxygen therapy; however, hemodynamic support is important for handling septic shock.

Though no antiviral treatments have been accepted, numerous methodologies have been suggested, such as lopinavir/ritonavir (400/100 mg every $12 \mathrm{~h}$ ), chloroquine (500 mg every $12 \mathrm{~h}$ ), alphainterferon (e. g., 5 million units by aerosol inhalation twice per day) and HCQ (200 mg every $12 \mathrm{~h}$ ). As of 23rd February 2020, seven clinical trial registries have been found in the Chinese Clinical Trial Registry for using HCQ to COVID-19 treatment. It has been described that the safe dosage of HCQ (6-6.5 mg/kg per day) could reach serum levels of 1.4-1.5 $\mu \mathrm{M}$ in humans [12].

The statement from the National Task Force for COVID-19 of the Indian Council of Medical Research (ICMR) dated March 21, 2020, commends the use of HCQ for prophylaxis in

(i) Asymptomatic healthcare workers tangled in the care of suspected and confirmed patients, and

(ii) Household contacts of confirmed patients with viral infection [13].

HCQ: chemistry and pharmacokinetics<smiles>CCN(CCO)CCCC(C)Nc1ccnc2cc(Cl)ccc12</smiles>

Fig. 1: Structure of HCQ 
HCQ belongs to a class of drugs known as 4-aminoquinolines [14]. It is absorbed rapidly and entirely after oral administration, partly proteinbound in plasma, and moderately metabolized in the liver via the cytochrome P450 (CYP) enzymes. HCQ is metabolized to one major metabolite, N-desethylhydroxychloroquine, by CYP enzymes CYP2D6, CYP2C8, CYP3A4, and CYP3A5 through the N-desethylation pathway. A relation has been shown between blood $\mathrm{N}$-desethylhydroxychloroquine levels and the effectiveness of treatment with HCQ [15].

\section{HCQ: anti-viral mechanism of action}

HCQ is generally considered immunomodulatory instead of immunosuppressant. It can restrict by the glycosylation of ACE2 (angiotensin-converting enzyme 2) then decrease the binding efficacy among ACE2 on the host cells and the spike protein present on the coronavirus surface. They can also raise the $\mathrm{pH}$ of endosomes and lysosomes, due to which the fusion method of the virus with host cells and resultant replication is forbidden. When HCQ enters
APCs (antigen-presenting cells), it avoids antigen processing and MHC class II-mediated auto antigen exposition to T cells. The further initiation of $\mathrm{T}$ cells then the appearance of CD154 and further cytokines are suppressed. Additionally, it interferes with the contact of DNA/RNA with TLRs (toll-like receptors) and the nucleic acid sensor cGAS (cyclic GMP-AMP synthase). So, the transcription of pro-inflammatory genes can't be stimulated and thus diminish the production of pro-inflammatory cytokines.

As a result, the administration of HCQ not only blocks the invasion and repetition of coronavirus but also decreases the opportunity of a cytokine storm. Such mechanisms give strong support to the hypothesis that HCQ is likely to have the capability to repress the CRS (cytokine release syndrome), which is due to over-activation of the immune system triggered by SARS-CoV-2 infection, through which continuation of the disease from mild to severe might be reduced. Still, suspicious clinical examination is instantaneously needed to validate this hypothesis $[16,17]$.
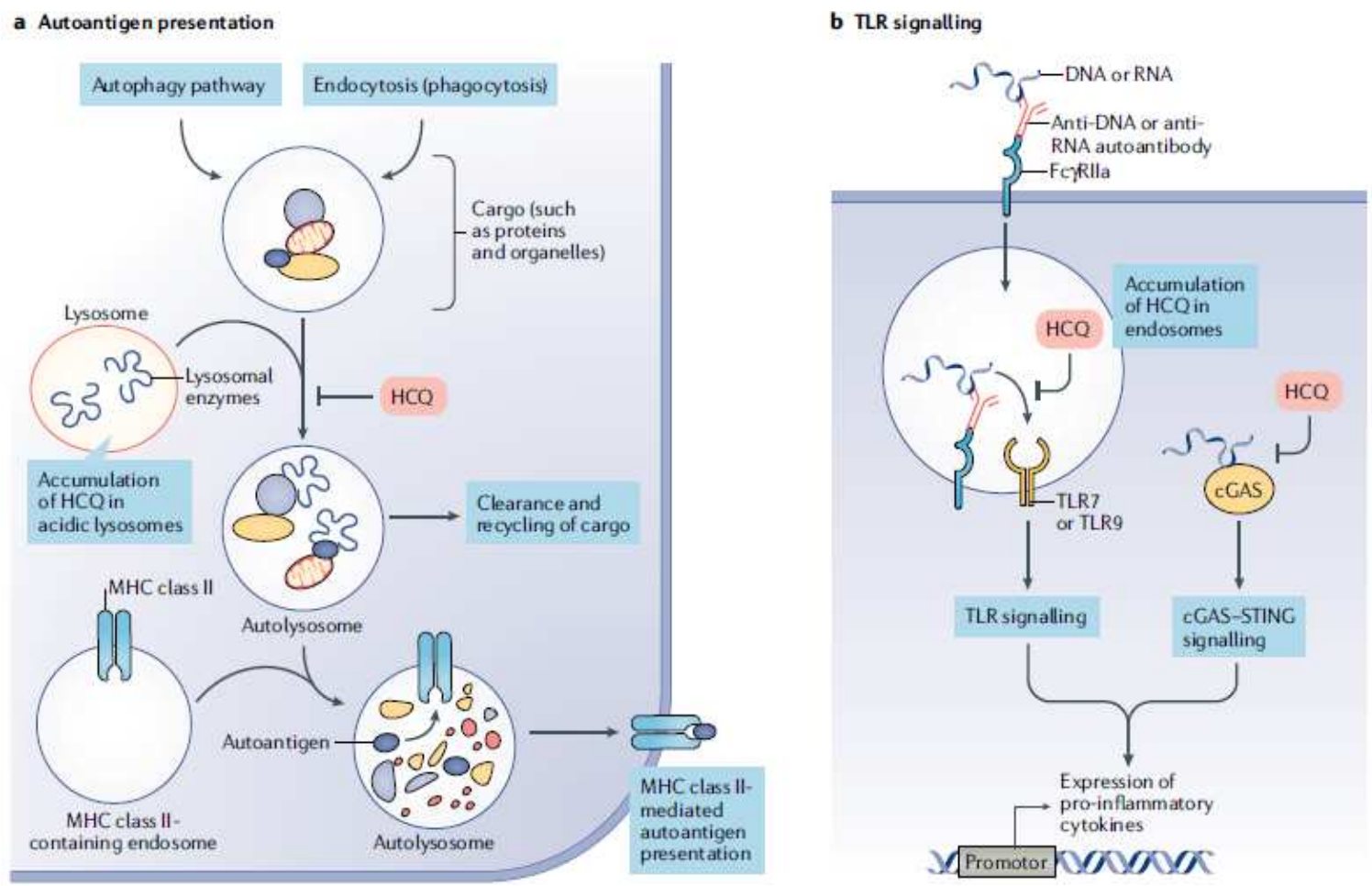

Fig. 2: Potential molecular mechanisms of HCQ [14]

a. HCQ enters and collects in lysosomes sideways the $\mathrm{pH}$ gradient. Inside lysosomes, it inhibits the degeneration of cargo (such as proteins and organelles) derived internally (via the autophagy pathway) or externally (via phagocytosis or endocytosis) in autolysosomes by accumulative the $\mathrm{pH}$ to check the activity of lysosomal enzymes. Inhibition of lysosomal activity can stop MHC class II-mediated autoantigen presentation. b. HCQ can also bind to the minor groove of double-stranded DNA by accumulating in endosomes. This drug can suppress Toll-like receptor (TLR) signaling by varying the $\mathrm{pH}$ of endosomes (involved in TLR processing) and/or inhibiting TLR7 and TLR9 from binding their ligands (RNA and DNA, respectively). It can also prevent the movement of the nucleic acid sensor cyclic GMP-AMP (cGAMP) synthase (cGAS) by interfering with its binding to cytosolic DNA. By preventing TLR signaling and cGAS-stimulator of interferon genes (STING) signaling, HCQ can decrease the production of proinflammatory cytokines, including type I interferons [14].

\section{HCQ: side effects in COVID-19 infected patients}

Despite generally safe profiles of CQ and HCQ when used at a low dose, both drugs can have important adverse effects, typically cardiovascular side effects. Numerous adverse effects of CQ and HCQ has been found on cardiac function and conduction, which can be fatal. These drugs are proarrhythmic and have an anti-arrhythmic property. These drugs have been registered by the American Heart Association as the agents, which can cause direct myocardial toxicity and aggravate myocardial dysfunction [18].

Alexandre et al. surveyed on 'Off-label' use and cardiac adverse drug reactions of HCQ, azithromycin, lopinavir-ritonavir, and chloroquine behaviors in COVID-19 [19]. Based on the experimental properties, HCQ (in particular) along with CQ, macrolide antibiotic azithromycin (AZI), and anti-HIV protease inhibitor lopinavir (LOPI) have been suggested and used for the treatment of COVID-19 [20, 21]. All kinds of clinical trials and observational studies have been applied to these four drugs worldwide [22-25]. But no strong or considerable data has yet been published about their effectiveness in COVID-19, as these four drugs have performed poorly so far. On the other hand, their safety, related to their tendency to prolong the QT interval of the electrocardiogram, remains challenging [26]. These drugs are accompanied by a risk of QT prolongation and 'serious' cardiac arrhythmias imaginably leading to cardiac arrest and sudden death. In their survey, out of 120 reports, 103 (85.8\%) were linked with the 
use of HCQ. The reports related to HCQ represented $100 \%$ of the reports of sudden, unexplained, or aborted deaths and $7 \%$ of the 120 reports of ADRs, $75 \%$ of the ventricular arrhythmias. EMA (European Medical Agency) and FDA (Food and Drug Administration) have defined the use of HCQ in COVID-19 to just clinical trials. QTc prolongation and resulting arrhythmogenic risk is the most perturbing ADR for these drugs in COVID-19.

Prescribing HCQ in patients with schizophrenia could also be a challenging clinical situation. HCQ is known to cause a spectrum of psychiatric adverse effects, including agitation, depression, mania, confusion, insomnia, hallucinations, catatonia, and suicidal ideation. Hypoglycemia, idiosyncratic hypersensitivity reactions, and drug-drug interactions have also been testified with HCQ use, and many of these adverse effects can be dose-related [27]. There are also several reports of psychosis induced by HCQ in patients with no history of psychosis [28]. Patients with schizophrenia can have exacerbations of psychotic symptoms during HCQ therapy. Considering the current weak evidence base for the use of HCQ in the treatment of COVID-19 infection and the significant risk of psychotic exacerbation and QTc prolongation, it would be cautious to avoid HCQ in patients with schizophrenia [29].

Geleris et al. performed an observational study of HCQ in Hospitalized Patients with COVID-19. They observed the association between HCQ use and death at a huge medical center in New York City and related outcomes in patients who received HCQ with those in patients who did not, using a multivariable Cox model with inverse probability weighting according to the tendency score. From their observational study, they found that HCQ-treated patients were more severely ill at baseline than those who didn't receive HCQ [30]. So, the study should not be taken to rule out either profit or harm of HCQ treatment. However, their decisions do not support the use of HCQ at present, outside randomized clinical trials testing its effectiveness.

HCQ can cause heart conduction disorders, with QT interval prolongation, bundle branch block, AV block, and torsades de pointes [31]. On April 24, 2020, the FDA gives out a safety statement in contrast to the use of HCQ for COVID-19 outside of the hospital setting or a clinical trial due to the danger of heart rhythm problems [32]. Caution must be used when combining them with QTprolonging psychotropics. Likewise, hepatotoxic and epileptogenic, so caution must be exercised in patients with hepatic disease, or in combination with psychotropics that might be hepatotoxic or may minor the seizure threshold. Given HCQ's long half-life ( $40 \mathrm{~h})$, the potential for continuous adverse effects and drug-interactions may continue for days after the drug has been discontinued [33, 34].

Jankelson et al. found evidence of important QT prolongation and increased risk of arrhythmia in patients with COVID-19 accepting HCQ [35].

According to D'Cruz et al. [13], Firstly, there is no perfect pre-clinical or clinical confirmation yet, for representing the efficiency of HCQ as a prophylactic agent for COVID-19. And secondly, drug pharmacokinetics in distinct populations such as teenagers (less than $12 \mathrm{y}$ ), the elderly; and expectant and lactating mothers differ significantly from the general population. They are also at a larger risk of adverse effects due to HCQ [36-40].

Reports collected so far have recommended that several drugs could be possible candidates for the treatment of COVID-19, although the clinical efficiency of these drugs has not yet been fully assessed. Some of these drugs have been summarized in table 1 [41].

Table 1: Drugs used for the treatment of coronavirus disease (COVID-19)

\begin{tabular}{|c|c|c|c|c|}
\hline Drugs & Types & Mechanisms of action & Past evidence & Reference \\
\hline Chloroquine & 4-aminoquinoline & $\begin{array}{l}\text { Not clearly known, changes the pH of } \\
\text { endosomes and believed to prevent viral } \\
\text { entry, transport, and post-entry events }\end{array}$ & $\begin{array}{l}\text { Inhibits infection of cells by SARS-CoV-2 in } \\
\text { vitro, accepted for malaria action and } \\
\text { prophylaxis }\end{array}$ & [41] \\
\hline $\begin{array}{l}\text { Hydroxy } \\
\text { chloroquine }\end{array}$ & 4-aminoquinoline & $\begin{array}{l}\text { Not clearly known, changes the } \mathrm{pH} \text { of } \\
\text { endosomes and believed to prevents viral } \\
\text { entry, transport, and post-entry events }\end{array}$ & $\begin{array}{l}\text { Prevents infection of cells by SARS-CoV-2 in } \\
\text { vitro, approved for malaria prophylaxis and } \\
\text { autoimmune disease (e.g. rheumatic } \\
\text { diseases). Approved for the treatment of } \\
\text { T2DM in India }\end{array}$ & \\
\hline Lopinavir/ & Protease & Blocks viral cellular entry & Effective against SARS-CoV 1 both in vitro & \\
\hline Ritonavir & inhibitors & & $\begin{array}{l}\text { and human studies, approved for HIV-1 } \\
\text { treatment }\end{array}$ & \\
\hline $\begin{array}{l}\text { Darunavir/ } \\
\text { Cobicistat }\end{array}$ & $\begin{array}{l}\text { Protease } \\
\text { inhibitors }\end{array}$ & Blocks viral cellular entry & $\begin{array}{l}\text { Established anti-HIV medication. No activity } \\
\text { against coronaviruses or other respiratory } \\
\text { viruses. No in vitro or clinical data. }\end{array}$ & \\
\hline Favipiravir & $\begin{array}{l}\text { RNA polymerase } \\
\text { inhibitors }\end{array}$ & Inhibits viral RNA-dependent polymerase & $\begin{array}{l}\text { Broad-spectrum antiviral against influenza, } \\
\text { arenavirus, bunyavirus, and filovirus }\end{array}$ & \\
\hline Remdesivir & $\begin{array}{l}\text { Adenosine nucleotide } \\
\text { analogue }\end{array}$ & Inhibits viral application & Effective against SARS and MERS & \\
\hline Ribavirin & $\begin{array}{l}\text { Nucleoside } \\
\text { analogue }\end{array}$ & $\begin{array}{l}\text { Inhibits viral RNA synthesis and mRNA } \\
\text { capping }\end{array}$ & $\begin{array}{l}\text { No evidence in SARS (potential harm) and } \\
\text { MERS }\end{array}$ & \\
\hline Baloxivir & Viral & Inhibits influenza virus multiplication & Approved for uncomplicated influenza only. & \\
\hline marboxil & $\begin{array}{l}\text { Endonuclease } \\
\text { inhibitor }\end{array}$ & & Oral route. & \\
\hline $\begin{array}{l}\text { Tocilizumab, } \\
\text { Sarilumab } \\
\text { Eculizumab }\end{array}$ & $\begin{array}{l}\text { Monoclonal } \\
\text { antibody }\end{array}$ & IL-6 inhibitor blocks the cytokine storm. & $\begin{array}{l}\text { No data on SARS or MERS. Tocilizumab } \\
\text { reduced fever and oxygen requirement in } \\
\text { COVID-19, accepted for rheumatoid } \\
\text { arthritis. }\end{array}$ & \\
\hline $\begin{array}{l}\text { SARS-Cov-2 } \\
\text { specific } \\
\text { antibodies }\end{array}$ & Antibody & $\begin{array}{l}\text { Binds to the virus and block infection } \\
\text { bind to infected cells and modification in } \\
\text { the immune system }\end{array}$ & Inhibits SARS-CoV-2 entry into cells in vitro & \\
\hline
\end{tabular}

*SARS-severe acute respiratory syndrome, MERS-Middle-East respiratory syndrome, HIV-Human Immunodeficiency syndrome, T2DM: type 2 diabetes, COVID-19-Coronavirus disease 19.

Several evidences revealed that HCQ and CQ showed a potential use against the COVID-19:
Singh AK et al. (2020) studied that the small cost of chloroquine and HCQ might also be an operational approach to counter COVID-19 (mostly in patients with diabetes and other co-morbidities in whom mortality is high) in resource-constrained and COVID-19 overloaded health care systems in middle-and low-income counties including India [41]. 
Liu Jia et al. (2020) revealed that HCQ could powerfully inhibit SARS-CoV-2 infection in vitro. In combination with its antiinflammatory activity, they predict that the drug has better potential to encounter the disease. This chance awaits verification by clinical trials. They figure out that HCQ is less lethal than CQ, prolonged and overdose usage can still cause poisoning. And the comparatively low SI of HCQ needs careful designing and conducting clinical trials to achieve efficient and safe control of the SARS-CoV-2 infection [42].

\section{CONCLUSION}

Following the major outbreak against COVID-19 infection due to the Sars-CoV-2 virus, HCQ and CQ were revealed as a potential drug for the treatment of this virus. Unlike antiviral drugs, HCQ has no direct effect on SARS-CoV-2. Its use against COVID-19, even as prophylaxis, has to be constantly supervised, specifically in individuals with previous heart conditions. The low cost of chloroquine and HCQ could also be an effective strategy to counter COVID-19. In combination with its anti-inflammatory function, it has been predicted that the drug has shown a good potential to fight the disease. Currently, HCQ combined with azithromycin quickly emerged in several countries as one of the most effective treatments for patients. However, HCQ needs careful designing and conducting clinical trials to achieve efficient and safe control of the COVID-19.

\section{FUNDING}

Nil

\section{AUTHORS CONTRIBUTIONS}

All the author has contributed equally.

\section{CONFLICT OF INTERESTS}

Declared none

\section{REFERENCES}

1. Ben Zvi I, Kivity S, Langevitz P, Shoenfeld Y. Hydroxychloroquine: from malaria to autoimmunity. Clin Rev Allergy Immunol 2012;42:145-53.

2. Wallace DJ, Metzger AL, Stecher VJ, Turnbull BA, Kern PA. Cholesterol-lowering effect of hydroxychloroquine in patients with rheumatic disease: reversal of deleterious effects of steroids on lipids. Am J Med 1990;89:322-6.

3. Chen PH, Huang YF, Tang CW, Wann SR, Chang HT. Kikuchifujimoto disease: an amazing response to hydroxychloroquine. Eur J Pediatr 2010;169:1557-9.

4. Rezai K, Kuchipudi S, Chundi V, Ariga R, Loew J, Sha BE. Kikuchi-fujimoto disease: HCQ as a treatment. Clin Infect Dis 2004;39:e124-6.

5. DeSimone DP, Brilliant HL, Basile J, Bell NH. Granulomatous infiltration of the talus and abnormal vitamin $\mathrm{D}$ and calcium metabolism in a patient with sarcoidosis: successful treatment with hydroxychloroquine. Am J Med 1989;87:694-6.

6. O'Leary TJ, Jones G, Yip A, Lohnes D, Cohanim M, Yendt ER. The effects of chloroquine on serum 1,25-dihydroxyvitamin D and calcium metabolism in sarcoidosis. N Engl J Med 1986;315:727-30.

7. Shimoni A, Hershcovici T, Mekhmandarov S, Maor Kendler Y, Beigel Y. Skeletal sarcoidosis: successful treatment with hydroxychloroquine. Isr Med Assoc J 2000;2:558-9.

8. Keyaerts E, Vijgen L, Maes P, Neyts J, Van Ranst M. In vitro inhibition of severe acute respiratory syndrome coronavirus by chloroquine. Biochem Biophys Res Commun 2004;323:264-8.

9. incent MJ, Bergeron E, Benjannet S. Chloroquine is a potent inhibitor of SARS coronavirus infection and spread. Virol J 2005;2:69.

10. Keyaerts E, Li S, Vijgen L. Antiviral activity of chloroquine against human coronavirus OC43 infection in newborn mice. Antimicrob Agents Chemother 2009;53:3416-21.

11. Cascella M, Rajnik M, Cuomo A, Dulebohn SC, Di Napoli R. Features, evaluation and treatment coronavirus (COVID-19). In: StatPearls. Treasure Island (FL): StatPearls Publishing; 2020.

12. Kapoor KM, Kapoor A. Role of chloroquine and HCQ in the treatment of COVID-19 infection-a systematic literature review. Medrxiv; 2020.
13. D'Cruz M. The ICMR bulletin on targeted HCQ prophylaxis for COVID-19: need to interpret with caution. Indian J Med Ethics 2020;5:100-2.

14. Schrezenmeier E, Dorner T. Mechanisms of action of hydroxychloroquine and chloroquine: implications for rheumatology. Nat Rev Rheumatol 2020;16:155-66.

15. Shrivastava Alankar. Analytical methods for the determination of hydroxychloroquine in various matrices. Int J Appl Pharm 2020;12:55-61.

16. Zhou D, Dai SM, Tong Q. COVID-19: a recommendation to examine the effect of hydroxychloroquine in preventing infection and progression. J Antimicrob Chemother 2020;75:1667-70.

17. Fantini J, Di Scala C, Chahinian H, Yahi N. Structural and molecular modeling studies reveal a new mechanism of action of chloroquine and HCQ against SARS-CoV-2 infection. Int J Antimicrob Agents 2020;55:105960.

18. Naksuk N, Lazar S, Peeraphatdit TB. Cardiac safety of off-label COVID-19 drug therapy: a review and proposed monitoring protocol. Eur Heart J Acute Cardiovasc Care 2020;9:215-21.

19. Gerard A, Romani S, Fresse A. "Off-label" use of hydroxychloroquine, azithromycin, lopinavir-ritonavir and chloroquine in COVID-19: a survey of cardiac adverse drug reactions by the french network of pharmacovigilance. Therapie 2020;75:371-9.

20. Gao J, Tian Z, Yang X. Breakthrough: chloroquine phosphate has shown apparent efficacy in the treatment of COVID-19 associated pneumonia in clinical studies. Biosci Trends 2020;14:72-3.

21. Wang M, Cao R, Zhang L. Remdesivir and chloroquine effectively inhibit the recently emerged novel coronavirus (2019-nCoV) in vitro. Cell Res 2020;30:269-71.

22. Dixon DL, Van Tassell BW, Vecchie A. Cardiovascular considerations in treating patients with coronavirus disease 2019 (COVID-19). J Cardiovasc Pharmacol 2020;75:359-67.

23. Guan WJ, Ni ZY, Hu Y, Liang WH, Ou CQ, He JX, et al. Clinical characteristics of coronavirus disease 2019 in China. N Engl J Med 2020;382:1708-20.

24. Cortegiani A, Ingoglia G, Ippolito M, Giarratano A, Einav S. A systematic review on the efficacy and safety of chloroquine for the treatment of COVID-19. J Crit Care 2020;57:279-83.

25. Dong L, Hu S, Gao J. Discovering drugs to treat coronavirus disease 2019 (COVID-19). Drug Discovery Ther 2020;14:58-60.

26. Balevic SJ, Hornik CP, Green TP. Hydroxychloroquine in patients with rheumatic disease complicated by COVID-19: clarifying target exposures and the need for clinical trials. J Rheumatol 2020;49:1424-30.

27. Smulyan H. The computerized ECG: friend and foe. Am J Med 2019;132:153-60.

28. Juurlink DN. Safety considerations with chloroquine, hydroxychloroquine and azithromycin in the management of SARS-CoV-2 infection. CMAJ 2020;192:E450-3.

29. Uvais NA. The risks of prescribing hyodroxychloroquine in COVID-19-infected patients with schizophrenia. Prim Care Companion CNS Disord 2020;22:20com02635. Doi:10.4088/ PCC.20com 02635.

30. Geleris J, Sun Y, Platt J, Zucker J, Baldwin M, Hripcsak G, et al. Observational study of HCQ in hospitalized patients with COVID-19. N Engl J Med 2020;382:2411-8.

31. McGhie TK, Harvey P, Su J, Anderson N, Tomlinson G, Touma Z. Electrocardiogram abnormalities related to antimalarials in systemic lupus erythematosus. Clin Exp Rheumatol 2018;36:545-51.

32. FDA cautions against use of HCQ or chloroquine for COVID-19 outside of the hospital setting or a clinical trial due to the risk of heart rhythm problems FDA; 2020. Available from: https://www.fda.gov/media/137250/download. [Last accessed on 20 Apr 2020].

33. Manufacturer's Package Insert, HCQ. Available from: https://www.accessdata.fda.gov/drugsatfda_docs/label/2017/ 009768s037s045s047lbl.pdf. [Last accessed on 20 Apr 2020]

34. Bilbul M, Paparone P, Kim AM, Mutalik S, Ernst CL. Psychopharmacology of COVID-19. Psychosomatics 2020:1-17. https://doi.org/10.1016/j.psym.2020.05.006 
35. Jankelson L, Karam G, Becker ML, Chinitz LA, Tsai MC. QT prolongation, torsades de pointes and sudden death with short courses of chloroquine or HCQ as used in COVID-19: a systematic review. Heart Rhythm 2020;17:1472-9.

36. Centers for Disease Control and Prevention. Coronavirus Disease 2019 (COVID-19). CDC; 2020. Available from: https://www.cdc.gov/coronavirus/2019-ncov/hcp/therapeuticoptions.html. [Last accessed on 25 Mar 2020].

37. World Health Organization. Coronavirus disease (COVID-19) technical guidance: Patient management. Geneva: WHO; 2019. Available from: https://www.who.int/emergencies/diseases/ novelcoronavirus 2019/technicalguidance/patientmanagement . [Last accessed on 25 Mar 2020].

38. World Health Organisation. Guidelines for the treatment of malaria. $3^{\text {rd }}$ edition. Geneva: WHO; 2015. Available from: https://www.who.int/malaria/publications/atoz/9789241549 $127 /$ en/. [Last accessed 16 Apr 2020]

39. Prescriber's Digital Reference. HCQ sulfate: Drug Summary. PDR. net. date unknown. Available from: https://www.pdr.net/ drug-summary/Plaquenil-HCQsulfate-1911. [Last accessed on 16 Apr 2020]

40. Ferner RE, Aronson JK. Chloroquine and hydroxychloroquine in covid-19. Br Med J 2020;369:m1432.

41. Singh AK, Singh A, Shaikh A, Singh R, Misra A. Chloroquine and hydroxychloroquine in the treatment of COVID-19 with or without diabetes: a systematic search and a narrative review with a special reference to India and other developing countries. Diabetes Metab Syndr 2020;14:241-6.

42. Liu J, Cao R, Xu M. Hydroxychloroquine, a less toxic derivative of chloroquine, is effective in inhibiting SARS-CoV-2 infection in vitro. Cell Discovery 2020;6:16. 